Dragan Nonić1, Jelena Nedeljković², Nenad Ranković3 ${ }_{1}^{1}$ University of Belgrade, Faculty of Forestry, Serbia 2University of Belgrade, Faculty of Forestry, Serbia ${ }^{3}$ University of Belgrade, Faculty of Forestry, Serbia

\title{
Small and Medium Enterprises Based on Non-Wood Forest Products: Characteristics and Types in Serbia
}

UDC: $338.45: 630(497.11) ; 630 * 8(497.11)$

DOI: 10.7595/management.fon.2014.0024

XIV International Symposium SymOrg 2014, 06 - 10 June 2014, Zlatibor, Serbia

In order to increase the contribution of the forestry sector to economic and social development, it is necessary to support the establishment and development of small and medium-sized enterprises (SMEs) whose business is based on wood and non-wood forest products (NWFPs). To properly plan the development of the private forestry sector, it is also necessary to establish the basic structure and forms of SMEs for procurement, processing and sale of NWFPs (NWFP-SMEs) as well as their business. In this context, the aim of the research was to determine the characteristics and types of NWFP-SMEs. The study included 91 representatives of NWFP-SMEs in Central Serbia. The analysis of the results showed that, based on the characteristics and activities they perform, there are three types of NWFP-SMEs. Based on the characteristics and attitudes towards additional training, four types of NWFP-SMEs representatives can be distinguished. The results can serve as a basis for further study on types of SMEs and improving the entrepreneurship in NWFP sector.

Keywords: small and medium enterprises, entrepreneurship, types, non-wood forest products, forestry

\section{Introduction}

Small and medium-sized enterprises (SMEs) have an important role in every economic sector, primarily due to “...contribution to social stability and significant fiscal revenues generation" (Premović, Boljević, \& Arsić, 2011). In order to increase the contribution of the forestry sector to the economic and social development, it is necessary to support the establishment and development of forest-based SMEs (Ranković, Nonić, Nedeljković, Marinković, \& Glavonjić, 2012). To properly plan the development of the private forestry sector and ensure the development of SMEs in forestry, it is necessary, in addition to wood products, to pay special attention to non-wood forest products ${ }^{1}$ (NWFPs).

Previous research shows that entrepreneurs in the forestry sector, when exploring new development strategies, should take NWFPs into account as these products provide significant opportunities for additional revenues (Niskanen et al., 2007). In this paper, the NWFPs are taken to be mushrooms, medicinal and aromatic plants (MAP), wild berries and other forest fruits (WBFF).

Research on SMEs for procurement, processing and selling of NWFPs (NWFP-SMEs) in Serbia argues that the structure of these enterprises is very heterogeneous, and production capacities are underutilized and often inadequate. One of the reasons for this may be the lack of adequate support, as it was determined that most of these enterprises do not have sufficient financial resources, nor do they have access to favourable bank loans (Nonić, Nedeljković, \& Jovanović, 2012; Nonić, Ranković, \& Nedeljković, 2013a). 
The results of research conducted in different countries indicate that SMEs need more support in order to enlarge and improve production capacities, obtain the necessary technical knowledge and increase profitability (Pettenella, Secco, \& Maso, 2007; Uddin et al., 2008). However, there is a lack of support for the development of SMEs in forestry in many countries; if any support exists, it is often inadequate or poorly targeted (Macqueen, 2007). Therefore, policy-makers may need "...policies that support the varying needs of different types of entrepreneur, rather than provide broad 'blanket' policies to all types of entrepreneurs, irrespective of need or ability" (Westhead, Ucbasaran, Wright, \& Binks 2005, p. 110). For these reasons, it is essential that decision-makers obtain necessary information about the types of enterprises in the private forestry sector, in this case NWFP-SMEs.

In literature, there are several typologies of entrepreneurs (Dowell, Dawson, Fuller-Love, \& Hopkins, 2012; Schwienbacher, 2007; Westhead et al., 2005), and SMEs (Andersén, 2012; Franco \& Haase, 2013; Swoboda \& Olejnik, 2013). Also, some authors have studied types of business strategies, which are not directly related to SMEs, but can be applied to them (Grant, Cadden, Mclvor, \& Humphreys, 2013; Löfving, Säfsten, \& Winroth, 2014; Miller \& Roth, 1994).

Previous studies in the private forestry sector in Serbia have determined several types of classification, in relation to: private forest owners (Nonić, Ranković, Glavonjić, \& Nedeljković, 2013); SMEs and entrepreneurs operating with wood products (Ranković et al., 2012); supply chains of NWFPs (Nonić, Ranković, \& Nedeljković, 2013b), and the attitudes of representatives of NWFP-SMEs towards the documentation needed for NWFPs collection (Nedeljković et al., 2013).

However, there is a lack of knowledge about the types of NWFP-SMEs and their representatives. For these reasons, the aim of the research was to determine the characteristics and types of NWFP-SMEs in Central Serbia $^{2}$. The purpose of the research is to create a basis for further research and improvement of the entrepreneurship in the NWFP sector. The subjects are attitudes of the representatives of NWFP-SMEs.

\section{Methods}

Different scientific methods are applied in the paper: statistical, comparative, analysis and synthesis. As a research technique for data collection, the "door-to-door" survey was used (Malhotra, 2007). The questionnaire was created as a combination of 65 open- and close-ended questions, divided into six groups. Only those questions that relate to the basic characteristics of NWFP-SMEs and their business, and basic (socio-demographic) characteristics of the respondents, were selected for the purposes of this paper.

During the statistical processing of answers to questions that were continuous variables the descriptive statistics was used, while in the case of categorical variables the frequency analysis was applied. The cluster analysis was used as statistical analysis, which is mainly applied in determining the specific typology in socio-economic studies (Grant et al., 2013; Swoboda \& Olejnik, 2013).

To group objects into relatively homogeneous groups (so-called clusters), i.e., to determine the types of SMEs and theirs representatives, a two-step cluster analysis (Malhotra, 2007) was applied. The criterion for clustering was the Schwarz's Bayesian Criterion (BIC). The two-step cluster analysis allows grouping of categorical, and categorical and non-categorical variables and does not require a prior knowledge of a number and characteristics of clusters. Those are determined by the value of BIC and Ratio of distance measures (RDM). The quality of the grouping is determined on the basis of Silhouette coefficient ${ }^{3}$. To test the differences in the obtained (empiric) and expected frequencies ${ }^{4}, x^{2}$ test for goodness-of-fit was used.

\footnotetext{
2 Term "Central Serbia" refers to the territory of Serbia without AP Vojvodina and Kosovo and Metohija.

${ }^{3}$ If the average value of Silhouette is $0.70-1$, quality of data grouping is strong, if $>0.50$ and $\leq 0.70$, quality is reasonable, if $>0.25$ and $\leq 0.50$, quality is week, and if $\leq 0.25$, grouping is not statistically significant (Pearson et al., 2004).

${ }^{4}$ In all cases it was assumed that expected (hypothetical) frequency distribution was 50\%:50\%, i.e., the null hypothesis was that all proportions were equal.
} 


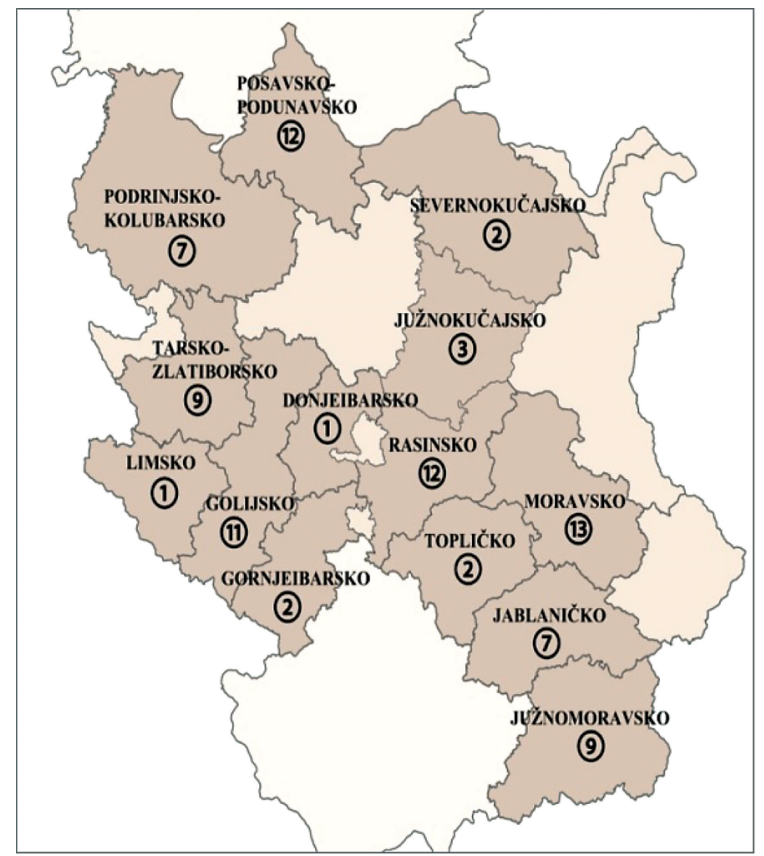

Map 1. Distribution of analyzed SMEs in forest areas

The basic information (name, registered office, contact) on NWFP-SMEs were obtained from internal reports of the Ministry of Environment, Mining and Spatial Planning ${ }^{5}$, whose responsibility these tasks were in the research period (2011-2012). Data collection was conducted with representatives of 91 enterprises (from the total number of 127 SMEs active at the moment of research) ${ }^{6}$. The distribution of these SMEs in forest areas ${ }^{7}$ is shown in . Sampling was not used in the research, i.e. the census was conducted because of the small population (Malhotra, 2007).

\section{Results}

In the results are presented and analysed the data related to characteristics and types of NWFP-SMEs and their representatives.

\subsection{Characteristics and types of NWFP-SMEs}

As basic characteristics of NWFP-SMEs in this research the following are considered (Table 1):

- location;

- number of employees and seasonal workers;

- type of NWFPs;

- transportation equipment and mechanization.

5 In accordance to the Decree on putting under control the use of and trade in wild flora and fauna, all legal entities engaged in collection of NWFPs for commercial purposes are obliged to have a permit. The register of these legal entities is kept, based on the data from the permits. ${ }^{6}$ After determining the final number of SMEs that asked for the permit for commercial collection of NWFPs in the period 2007-2010, their liquidity was verified (telephone contact and checking databases of the Serbian Business Register Agency and the National Bank of Serbia).

${ }^{7}$ Detailed information on forest areas are given in the Law on forests (2010). 
Table 1. Share of NWFP-SMEs as regards basic characteristic

\begin{tabular}{|l|l|c|}
\hline NWFP-SMEs basic characteristics & Frequencies (\%) \\
\hline \multirow{3}{*}{ Location } & Rural & 70.3 \\
\cline { 2 - 3 } & Urban & $\mathbf{5 7 . 1}$ \\
\hline \multirow{4}{*}{ Tumber of employees } & Up to 10 & 31.9 \\
\cline { 2 - 3 } & $11-50$ & 49.5 \\
\cline { 2 - 3 } & $51-250$ & 18.7 \\
\hline \multirow{5}{*}{ Transportation equipment and } & Mushrooms & 62.6 \\
\cline { 2 - 3 } & MAP & 35.2 \\
\cline { 2 - 3 } & WBFF & 62.6 \\
\hline & Van with refrigerator & 42.9 \\
\cline { 2 - 3 } & Van without refrigerator & 60.4 \\
\cline { 2 - 3 } & Weighing machine & 95.6 \\
\cline { 2 - 3 } & Drying machine & 65.9 \\
\cline { 2 - 3 } & Machine for processing & 75.8 \\
\cline { 2 - 3 } & Machine for packaging & 22.0 \\
\cline { 2 - 3 } & Cold-store & 56.0 \\
\hline
\end{tabular}

In relation to the location, most NWFP-SMEs are located in urban, but also in rural areas while a certain number $(27.5 \%)$ of these perform business activities in both locations.

Around a half of NWFP-SMEs (49.5\%) have 11-50 employees. The results of $X^{2}$ test for goodness-of-fit show a statistically significant difference between these groups $\left(X^{2}=13.01, d f=2, p=0.00\right)$. As regards the number of employees, most enterprises belong to the group of small enterprises ${ }^{8}$.

Most NWFP-SMEs (84.6\%) hire seasonal workers, whose average number is 10 and maximum number amounts to 250. NWFP-SMEs need to hire seasonal workers because collection, purchase and processing of NWFPs are seasonal activities, mainly preformed during summer and autumn.

When it comes to type of NWFPs, most SMEs (62.2\%) are engaged in mushrooms and WBFF business and $35.2 \%$ in MAP.

Regarding transportation equipment and mechanization, most NWFP-SMEs have vans without refrigerator $(60.4 \%)$ and other equipment necessary for secondary processing of NWFPs (weighing machine, drying machine, machine for processing and cold-stores).

The oldest equipment, which enterprises purchased at the time of their establishment, are drying machines, vans, machines for processing (10 yrs.) and packaging (8 yrs.), and cold-stores (7 yrs.). The average age of weighing machines is smaller (5 yrs.), because they need to be renewed frequently.

Analysed major characteristic of NWFP-SMEs ${ }^{9}$ business are the following (Table 2):

- business activities;

- average use of technological capacity;

- working conditions;

- problems in business;

- relationship to investments.

\footnotetext{
${ }^{8}$ If only number of employees is taken as a criterion, these enterprises, in accordance with the current Law on accounting (from 2013), belong to the category of small enterprises.

${ }^{9}$ In relation to legal form, most enterprises are registered as business companies (74.7\% as Limited Liability Company and $1.1 \%$ as Joint Stock Company). In addition, there are entrepreneurs (22.0\%) and cooperatives (2.2\%).
} 
Table 2. Share of NWFP-SMEs as regards basic characteristic of business

\begin{tabular}{|c|c|c|}
\hline \multicolumn{2}{|c|}{ Basic characteristics of NWFP-SMEs business } & Frequencies (\%) \\
\hline \multirow{4}{*}{ Business activity } & Procurement & 98.9 \\
\hline & Processing & 95.6 \\
\hline & Selling & 68.1 \\
\hline & NWFPs main/sole activity & 73.6 \\
\hline \multirow{3}{*}{$\begin{array}{l}\text { Average utilization of } \\
\text { technological capacity }\end{array}$} & Coldstore & 57.6 \\
\hline & Drying machine & 74.8 \\
\hline & Equipment for other processing & 70.8 \\
\hline \multirow{3}{*}{ Working conditions } & Old equipment and mechanization & 14.6 \\
\hline & Dependence of weather conditions & 78.7 \\
\hline & Inadequate legal framework & 70.8 \\
\hline \multirow{11}{*}{ Problems in business } & Unqualified labour & 22.0 \\
\hline & Insufficient labour & 39.6 \\
\hline & Lack of training & 14.3 \\
\hline & Unfair competition & 60.4 \\
\hline & Lack of export & 16.5 \\
\hline & Undeveloped national market & 39.6 \\
\hline & Insufficient utilization of capacities & 27.5 \\
\hline & Payments & 39.6 \\
\hline & Clients & 9.9 \\
\hline & Cooperation with other enterprises & 11.0 \\
\hline & Other & 14.3 \\
\hline \multirow{5}{*}{ Investments } & Fixed assets of expanded reproduction & 74.1 \\
\hline & Product finalization & 17.6 \\
\hline & Introduction of additional activities & 7.1 \\
\hline & Marketing instruments & 7.1 \\
\hline & Working assets & 9.4 \\
\hline
\end{tabular}

Business activities of most NWFP-SMEs include procurement (98.9\%), processing (95.6\%) and selling (68.1\%). Also, NWFP-related business activities are the main or sole activity for around $3 / 4(73.6 \%)$ SMEs.

In the analysed enterprises, there is a high degree of utilization of drying machine $(74.8 \%)$ and equipment used for other processing $(70.8 \%)$, while the degree of utilization of cold-stores is slightly lower (57.6\%).

The respondents believe that working conditions are mostly defined by weather $(78.7 \%)$, which is understandable bearing in mind that NWFPs yield depends solely on nature and weather conditions. Also, the majority of respondents $(70.8 \%)$ claim that the legal framework is inadequate.

Unfair competition is the most important problem in business (60.4\% of SMEs representatives). Representatives also maintain that insufficient labour, undeveloped national market, and payments each (39.6\%) cause problems in business. On the other hand, the smallest number of respondents believe that problems are caused by clients $(9.9 \%)$ and cooperation with other enterprises $(11.0 \%)^{10}$.

Most SMEs representatives (74.1\%) believe that financial resources should be invested in new equipment, i.e. fixed assets.

Types of NWFP-SMEs were determined based on two groups of variables:

1) basic characteristics (location, number of employees and seasonal workers);

2) SMEs' activities.

${ }^{10}$ Most respondents believe that unfair competition represents „....problem in NWFP purchase”, while on the other hand the majority emphasize that they "... with other enterprises usually cooperate in selling". 
Three types ${ }^{11}$ of enterprises are distinguished based on the characteristics (Table 3):

1) "small rural" (50.6\%);

2) "small urban" (29.9\%);

3) "medium urban" (19.5\%).

Table 3. Types of enterprises in relation to the characteristics

\begin{tabular}{|l|c|c|c|}
\hline Type of enterprise & Location & Number of employees & Number of seasonal workers \\
\hline Small rural & Rural & $11-50$ & 16 \\
\hline Small urban & Urban & $11-50$ & 17 \\
\hline Medium urban & Urban & $51-250$ & 133 \\
\hline
\end{tabular}

Most SMEs belong to the type of "small rural enterprises", which is understandable bearing in mind that the activities related to NWFPs, particularly procurement of raw materials, belong to rural areas. This is because NWFPs collection and purchase are performed in villages and their surroundings, as they are closer to the forest resources in comparison with urban areas.

The results of $X^{2}$ goodness-of-fit test show a statistically significant difference between these types $\left(X^{2}=11.64\right.$, $\mathrm{df}=2, p=0.003)$.

"Small rural" and "small urban" types are very similar (differ only in location). On the other hand, the "medium urban" type clearly differs, both in terms of the number of employees and in the number of seasonal workers.

Three types of enterprises are determined, based on SMEs business activities ${ }^{12}$ :

1) SMEs engaged in procurement, processing and selling of NWFPs (64.8\%);

2) SMEs engaged in procurement, and processing of NWFPs $(30.8 \%)$;

3) SMEs engaged in procurement, and selling of NWFPs (4.4\%).

The results of $X^{2}$ goodness-of-fit test show a statistically significant difference between these types $\left(X^{2}=50.13\right.$, $\mathrm{df}=2, p=0.0)$.

The majority of enterprises belong to the type engaged in all three activities. This is understandable if one takes into account the above results, which indicates that procurement and processing are present in almost all studied SMEs while selling is present in the majority of them.

\subsection{Characteristics and types of representatives of NWFP-SMEs}

The following characteristics of representatives of NWFP-SMEs were analysed (Table 4):

- position;

- age;

- gender;

- education.

In terms of positions in the enterprise, $69.2 \%$ of all representatives NWFP-SMEs are owners and/or managers (27.5\% owners, $22.0 \%$ owner-managers and $19.8 \%$ managers). The presented results indicate that no position prevails. However, results of the $X^{2}$ goodness-of-fit test show a statistically significant difference between the observed variables $\left(x^{2}=40.31, \mathrm{df}=6, p=0.0\right)$.

\footnotetext{
11 Silhouette $=0.5, \mathrm{BIC}=253.87, \mathrm{RDM}=1.86$

12 Silhouette $=1.0, \mathrm{BIC}=55.23, \mathrm{RDM}=3.01$
} 
Table 4. Share of NWFP-SMEs representatives' as regards the characteristic

\begin{tabular}{|c|c|c|c|c|c|}
\hline \multirow{2}{*}{\multicolumn{2}{|c|}{ Characteristics }} & Owner & Manager & Owner-manager & All respondents \\
\hline & & \multicolumn{4}{|c|}{ Frequencies (\%) } \\
\hline \multirow{7}{*}{ Position } & Owner & 100 & - & - & 27.5 \\
\hline & Manager & - & 100 & - & 19.8 \\
\hline & Owner-manager & - & - & 100 & 22.0 \\
\hline & Employee & - & - & - & 17.6 \\
\hline & PR & - & - & - & 1.1 \\
\hline & Consultant & - & - & - & 1.1 \\
\hline & Other & - & - & - & 11.0 \\
\hline \multirow{4}{*}{ Age } & $18-25$ & - & - & - & 2.2 \\
\hline & $26-45$ & 52.0 & 27.8 & 55.0 & 49.5 \\
\hline & $46-65$ & 48.0 & 72.5 & 40.0 & 47.3 \\
\hline & More than 65 & - & - & 5.0 & 1.1 \\
\hline \multirow{2}{*}{ Gender } & Male & 84.0 & 83.3 & 75.0 & 74.7 \\
\hline & Female & 16.0 & 16.7 & 25.0 & 25.3 \\
\hline \multirow{3}{*}{ Education } & Secondary school & 40.0 & 22.2 & 55.0 & 41.8 \\
\hline & High school & 28.0 & 33.3 & 20.0 & 22.0 \\
\hline & Faculty & 32.0 & 44.4 & 25.0 & 36.3 \\
\hline
\end{tabular}

Regarding gender, representatives of SMEs are mostly males (74.7\%). The majority of owners and ownermanagers belong to the age group of 26-45 olds.

In relation to education, the results of $x^{2}$ goodness-of-fit test reveal no statistically significant difference between education categories ${ }^{13}$, i.e. none of them can be described as prevailing.

The following attitudes of NWFP-SMEs representatives, towards additional training were analysed (Table 5):

- importance of additional trainings;

- previous trainings;

- type of training;

- interest in future training;

- type of training required in future.

Table 5. Share of NWFP-SMEs representatives as regards attitudes toward training

\begin{tabular}{|c|c|c|c|c|c|}
\hline \multirow{2}{*}{\multicolumn{2}{|c|}{ Attitudes }} & Owner & Manager & $\begin{array}{l}\text { Owner- } \\
\text { manager }\end{array}$ & $\begin{array}{c}\text { All } \\
\text { respondents }\end{array}$ \\
\hline & & \multicolumn{4}{|c|}{ Frequencies (\%) } \\
\hline \multirow{3}{*}{$\begin{array}{l}\text { Importance of } \\
\text { additional } \\
\text { trainings } 14\end{array}$} & Negative & 8.0 & 11.1 & 5.0 & 7.7 \\
\hline & Indifferent & 28.0 & 11.1 & 15.0 & 16.5 \\
\hline & Positive & 64.0 & 77.8 & 80.0 & 75.8 \\
\hline \multirow{2}{*}{ Previous trainings } & Yes & 56.0 & 44.4 & 60.0 & 52.7 \\
\hline & No & 44.0 & 55.6 & 40.0 & 47.3 \\
\hline \multirow{2}{*}{ Type of training } & Informal & 7.1 & 28.6 & 25.0 & 15.2 \\
\hline & Formal & 92.9 & 71.4 & 75.0 & 84.8 \\
\hline \multirow{2}{*}{$\begin{array}{l}\text { Interest in future } \\
\text { trainings }\end{array}$} & Yes & 80.0 & 72.2 & 80.0 & 79.1 \\
\hline & No & 20.0 & 27.8 & 20.0 & 20.9 \\
\hline \multirow{7}{*}{$\begin{array}{l}\text { Type of training } \\
\text { required in future }\end{array}$} & Entrepreneurship & 42.9 & 30.8 & 37.5 & 35.6 \\
\hline & Business administration & 42.9 & 46.2 & 43.8 & 43.8 \\
\hline & Management & 57.1 & 61.5 & 37.5 & 53.4 \\
\hline & Supply chain management & 42.9 & 38.5 & 31.3 & 35.6 \\
\hline & Legislation & 42.9 & 38.5 & 37.5 & 35.6 \\
\hline & Professional knowledge on NWFPs & 66.7 & 61.5 & 75.0 & 68.5 \\
\hline & Other & 9.5 & 23.1 & 12.5 & 16.7 \\
\hline
\end{tabular}

${ }^{13}$ Values of $\chi 2$ goodness-of-fit test are: owners- $\chi 2=0.56, d f=2, p=0.76$; managers $-\chi 2=1.33, d f=2, p=0.51$, owner-managers- $\chi 2=4.3, d f=2$, $\mathrm{p}=0.12$.

${ }^{14}$ 5-degree Likert scale was applied for evaluation of additional training importance. In this paper, points 1 (very unimportant) and 2 (unimportant) are shown as negative, 3 (neither important nor unimportant) as indifferent, and 4 (important) and 5 (very important) as positive attitude. 
Most respondents have a positive attitude towards the importance of additional training. Also, most of them, except those in the position of managers, have attended some training courses, mostly formal. The majority of respondents, regardless of the position, showed an interest in attending training courses in the future. In relation to the type of training, $68.5 \%$ of respondents believe that they need professional knowledge on NWFP and $53.4 \%$ require training in management.

Types of NWFP-SMEs representatives (owner, manager and owner- manager), were distinguished on the basis of two groups of variables: basic characteristics and attitudes towards the type of training.

As regards characteristics (Table 6), the majority of owners $(52.0 \%)$ and the highest number of ownermanagers (45.0\%) are "younger secondary school graduates", and $44.4 \%$ of managers are "older secondary school graduates". Common characteristics of these types are male sex and secondary education.

Table 6. Share of types of NWFP-SMEs representatives as regards the basic characteristics

\begin{tabular}{|c|c|c|c|}
\hline \multirow{2}{*}{ Type 15 of NWFP-SMEs representatives } & Owner & Manager & Owner-manager \\
\hline & \multicolumn{3}{|c|}{ Frequencies (\%) } \\
\hline Younger secondary school graduates & 52.0 & - & 45.0 \\
\hline Older secondary school graduates & - & 44.4 & - \\
\hline Older high school graduates 16 & - & 16.7 & 20.0 \\
\hline Older with faculty & 48.0 & 38.9 & 35.0 \\
\hline
\end{tabular}

However, the results of $X^{2}$ goodness-of-fit test indicates no statistically significant difference between these types (none can be described as prevailing), because:

- for owners, $\mathrm{X}^{2}=0.04, \mathrm{df}=1, p=0.84$;

- for managers, $x^{2}=2.33, \mathrm{df}=2, p=0.31$;

- for owner-managers, $X^{2}=1.90, \mathrm{df}=2, p=0.39$.

Regarding attitudes toward type of training (Table 7), NWFP-SMEs representatives are classed as follows:

- "professional knowledge on NWFPs" - only professional knowledge of NWFPs, related to the type of product, methods of collection, processing, etc. (75\% owner-managers);

- "broad managerial \& professional knowledge" - knowledge in the field of management and related disciplines (entrepreneurship, business administration, etc.), and professional knowledge on NWFPs;

- "narrow managerial \& professional knowledge" - knowledge in the field of management, and professional knowledge on NWFPs (61.5\% of managers);

- "lack of interest in additional training in proposed fields" - no need for additional training in management and related disciplines, nor professional knowledge on NWFPs, but still show interest in additional education (61.9\% of owners).

Table 7. Share of types of NWFP-SMEs representatives as regards the type of training

\begin{tabular}{|l|c|c|c|}
\hline \multirow{2}{*}{ Type 17 of NWFP-SMEs representatives } & Owner & Manager & Owner-manager \\
\cline { 2 - 4 } & \multicolumn{3}{|c|}{ Frequencies (\%) } \\
\hline Professional knowledge on NWFPs & - & - & 75.0 \\
\hline Broad managerial \& professional knowledge & 38.1 & 38.5 & 25.0 \\
\hline Narrow managerial \& professional knowledge & - & 61.5 & - \\
\hline Lack of interest in additional training in proposed fields & 61.9 & - & - \\
\hline
\end{tabular}

\footnotetext{
15 Owners: Silhouette $=0.5, \mathrm{BIC}=99.85, \mathrm{RDM}=1.81$; managers: Silhouette=0.6, $\mathrm{BIC}=64.50, \mathrm{RDM}=1.66$; owner-managers: Silhouette $=0.5$, $\mathrm{BIC}=87.01, \mathrm{RDM}=1.53$.

16 Types of managers and owner-managers "older high school graduates" are 46-65 years old, with high school education. The difference is in gender: managers are females and owner-managers are males.

17 Owners: Silhouette=0.7, $\mathrm{BIC}=108.87, \mathrm{RDM}=4.28$; managers: Silhouette=0.5, $\mathrm{BIC}=93.01, \mathrm{RDM}=2.56$; owner-managers: Silhouette $=0.7$, $\mathrm{BIC}=101.37, \mathrm{RDM}=2.32$
} 
However, the results of $x^{2}$ test for goodness-of-fit show that there is no statistically significant difference between these types (none can be described as prevailing, except in case of owner-managers), because:

- for owners, $X^{2}=1.19, \mathrm{df}=1, p=0.28$;

- for managers, $X^{2}=0.69, \mathrm{df}=1, p=0.41$;

- for owner-managers, $X^{2}=4.0, \mathrm{df}=1, p=0.046$.

a common characteristic for owners, managers and owner-managers is that few of them show interest in acquiring "broad managerial \& professional knowledge".

\section{Discussion}

In relation to the basic characteristics of NWFP-SMEs, it can be seen that their location is both in urban and rural areas, and that they are small enterprises in terms of the number of employees. The most common NWFPs are mushrooms and WBFF. Most NWFP-SMEs belong to the type of "small rural enterprises".

Previous studies on forest-based enterprises indicate that small family enterprises (FAO, 2005; USAID, 2008) located in rural areas (FAO, 2005; Niskanen et al., 2007; Pettenella et al., 2007) are mainly engaged in these activities.

Regarding the characteristics of NWFP-SMEs business, it is noticeable that product sale is characteristic of most enterprises, while almost all of them are engaged in procurement and processing. The prevailing type of NWFP-SMEs, classified on the basis of their activities, is the one that integrates procurement, processing and selling. Previous studies in the region of Šumadija and Western Serbia showed similar results (Nonić, Ranković, \& Nedeljković, 2013b).

Most NWFP-SMEs representatives believe that working conditions are defined by weather. Considering that NWFPs are seasonal products whose yields depend on nature and weather "...their supply cannot be regular and fully reliable" (FAO, 2005, p. 6). This is the reason why SMEs in this sector "...seldom rely on one product" $(\mathrm{FAO}, 2005$, p. 6). In this way, they are trying to minimize potential losses.

Unfair competition, insufficient labour, underdevelopment of national market and payments are important problems in business. Although there are certain differences in attitudes, these problems are to some extent similar to those reported in the literature. Research conducted abroad show that the main problems are: "...lack of capital investment and shortage of raw materials, skilled manpower and up-to-date information" (Uddin et al., 2008, p. 147). Also, problems can be caused by "...financial and technical limitations, (...), market insecurity (with large price —uctuations) and lack of research" (Uddin et al., 2008, p. 148).

Despite appropriate technological equipment, most respondents believe that additional funds should be invested in fixed assets (cold-stores, drying machines, etc.). According to the results of previous research in Serbia, representatives of NWFP-SMEs emphasize the need for additional financial support measures to be used for the purchase of new equipment and machinery (Nonić, Ranković, \& Nedeljković, 2013a).

As regards the basic characteristics of NWFP-SMEs representatives, most respondents are owners and/or managers. The largest (but not prevailing) number of owners and owner-managers belong to the type of "younger secondary school graduates". This means that all of them are males, 26-45 years old, with secondary school. These results are in line with previous studies that indicate that entrepreneurs are mainly males, 20-50 years old, and have secondary school education (Ayala \& Manzano, 2014).

Most respondents have a positive attitude towards additional education and have attended some kind of formal training. In terms of types of NWFP-SMEs representatives, most owner-managers belong to the type being interested in professional knowledge on NWFPs. On the other hand, most owners show a lack of interest in additional training in the proposed fields. The reason for this may be the fact that "owner-managers" in forestry "...see their businesses primarily as a source of revenue and a way to provide for their own employment" (St-Jean, LeBel, \& Audet, 2010, p. 212). The importance of additional education is emphasized in previous studies showing that "...certain factors such as human capital and characteristics (education, training, manager experience) have a direct influence on rural business growth" (St-Jean et al., 2010, p. 213). 
Conslusion

With regard to characteristics of NWFP-SMEs, the following conclusion can be drawn:

- most enterprises have 11-50 employees and deal with mushrooms and/or WBFF;

- most enterprises have a van without refrigerator, weighing and drying machines, a machine for processing and cold-stores.

With regard to characteristics of NWFP-SMEs business, the following can be concluded:

- most enterprises are engaged in all three activities (procurement, processing, selling), and NWFPs are a predominant/sole activity;

- there is a high degree of utilization of drying machines and equipment for other processing;

- working conditions are defined by the dependence on weather and inadequate legal framework;

- the most important problem in business is "unfair competition";

- financial resources should be invested in fixed assets.

Research results show the following types of NWFP-SMEs:

- in terms of basic characteristics of SMEs:

1) "small rural" (prevailing);

2) "small urban";

3) "medium urban";

- In terms of business activities:

1) "procurement, processing, selling" (prevailing);

2) "procurement, processing";

3) "procurement, selling".

The following can be concluded in relation to the characteristics of NWFP-SMEs representatives:

- most are at the positions of the owner and/or manager, are 26-45 years old, male, with secondary school education;

- most have a positive attitude towards the importance of additional training, have attended formal training courses and show interest in additional education, mainly in the field of management and professional knowledge on NWFPs.

The following types of NWFP-SMEs representatives are distinguished:

- in terms of some basic characteristics (none is prevailing):

1) "younger secondary school graduates";

2) "older secondary school graduates";

3) "older high school graduates";

4) "older with faculty";

- in terms of attitudes toward the type of additional training:

1) "professional knowledge on NWFPs" (prevailing within owner-managers);

2) "broad managerial \& professional knowledge"

3) "narrow managerial \& professional knowledge"

4) "lack of interest in additional training in proposed fields".

These results can serve as a basis for further research on types of SMEs and opportunities for improvement of entrepreneurship in the NWFPs sector. Also, the need for specific support measures in relation to different types of entrepreneurs should be an object of study in the period to come.

Acknowledgment: This study was conducted within the project "Sustainable management of the overall potential of forests in the Republic of Serbia" (no. 37008-TR) and the project "Research on climate changes and their impact on the environment - monitoring of impacts, adaptation and mitigation" (no. 43007), subproject "Socio-economic development, mitigation and adaptation to climate changes" (no. 43007/16-III), funded by the Ministry of Education, Science and Technological development.

\section{REFERENCES}

[1] Andersén, J. (2012). A resource-based taxonomy of manufacturing MSMEs, International Journal of Entrepreneurial Behaviour \& Research 18(1), 98-122. doi:10.1108/13552551211201394

[2] Ayala, J.C., Mazano, G. (2014). The resilience of the entrepreneur. Influence on the success of the business. A longitudinal analysis. Journal of Economic Psychology. Advance online publication. doi:10.1016/j.joep.2014.02.004 
[3] Dowell, D., Dawson, C, Fuller-Love, N., \& Hopkins, B. (2012). Entrepreneurial groups in Ireland and Wales: A preliminary typology of entrepreneurs using a marketing segmentation approach. Journal of Research in Marketing and Entrepreneurship, 14(2), 184 - 198. doi:10.1108/14715201211271401

[4] FAO (2005). Microfinance and forest-based small-scale enterprises (FAO Forestry Paper 146). Rome: FAO.

[5] FAO (1999). Towards a harmonized definition of non-wood forest product. Unasylva, 198(50), 63-64.

[6] Franco, M., \& Haase, H. (2013). Interfirm Alliances: A Taxonomy for SMEs. Long Range Planning. Advance online publication, doi:10.1016/j.Irp.2013.08.007

[7] Grant, N., Cadden, T., Mclvor, R., \& Humphreys, P. (2013). A taxonomy of manufacturing strategies in manufacturing companies in Ireland. Journal of Manufacturing Technology Management 24(4), $488-510$. doi: $10.1108 / 17410381311327378$

[8] Law on forests (2010). Official Gazette of the Republic of Serbia 30/10, Belgrade.

[9] Löfving, M, Säfsten, K., \& Winroth, M. (2014). Manufacturing strategy frameworks suitable for SMEs. Journal of Manufacturing Technology Management 25(1), (7-26). doi:10.1108/JMTM-08-2012-0081

[10] Macqueen, D. (2007). The role of small and medium forest enterprise associations in reducing poverty. London: IIED.

[11] Malhotra, N. (2007). Marketing research-an applied orientation. Upper Saddle River: Pearson Prentice Hall.

[12] Miller, J. G., \& Roth, A. V. (1994). A Taxonomy of Manufacturing Strategies. Management Science, 40(3), 285-304.

[13] Nedeljković, J., Lovrić, M., Nonić, D., Stojanovska, M., Nedanovska, V., Lovrić, N., Stojanovski, V. (2013). Utjecaj političkih instrumenata na poslovanje sa nedrvnim šumskim proizvodima u Hrvatskoj, Makedoniji i Srbiji, [Influence of policy instruments on non-wood forest products commercialization in Croatia, Macedonia and Serbia]. Šumarski list 9-10, 473-486.

[14] Niskanen, A., Slee, B., Ollonqvist, P., Pettenella, D., Bouriaud, L., Rametsteiner, E. (2007). Entrepreneurship in the forest sector in Europe. Silva Carelica 52, Joensuu: University of Joensuu, Faculty of Forestry.

[15] Nonić, D., Nedeljković, J., \& Jovanović, M. (2012). Organizacija elemenata internog lanca snabdevanja nedrvnim šumskim proizvodima u Posavsko-podunavskom šumskom području [Organisation of NWFPs internal supply chain elements in Posavsko-podunavsko forest area]. Šumarstvo 3-4, 83-96.

[16] Nonić, D., Ranković, N., Glavonjić, P., \& Nedeljković, J. (2013). Tipologija vlasnika privatnih šuma u Srbiji [Typology of private forest owners in Serbia]. Šumarstvo 3-4, 133-156.

[17] Nonić, D., Ranković ,N., \& Nedeljković, J. (2013a). Institucionalni okviri i finansijska podrška preduzećima koja posluju sa nedrvnim šumskim proizvodima u EU i Jugoistočnoj Evropi [Institutional framework and financial support to non-wood forest products-based enterprises in EU and Southeast Europe]. Šumarstvo 3-4, 85-111.

[18] Nonić, D., Ranković ,N., \& Nedeljković, J. (2013b). Tipologija lanaca snabdevanja nedrvnim šumskim proizvodima u centralnoj Srbiji [Typology of the supply chains of non $\square$ wood forest products in Central Serbia]. Glasnik Šumarskog fakulteta 108, 145-168. doi:10.2298/GSF1308147N

[19] Pearson, R.K., Zylkin, T., Schwaber, J., \& Gonye G.E. (2004). Quantitative evaluation of clustering results using computational negative controls. In Berry M. (ed.), Proceedings of the Fourth SIAM International Conference on Data Mining, Society for Industrial and Applied Mathematics (pp. 188-199). Lake Buena Vista: SIAM.

[20] Pettenella, D., Secco, L., \& Maso, D. (2007). NWFP\&S Marketing: Lessons Learned and New Development Paths from Case Studies in Some European Countries. Small-scale Forestry 6(4), 373-390. doi:10.1007/s11842-007-9032-0

[21] Premović, J., Boljević, A., \& Arsić, LJ. (2011). Mala i srednja preduzeća kao generatori održivog regionalnog razvoja [Small and medium enterprises as generators of the sustainable regional development]. Ekonomika poljoprivrede 58(SB1), 137-144.

[22] Ranković, N., Nonić, D., Nedeljković, J., Marinković, M., Glavonjić, P. (2012). Mala i srednja preduzeća u Timočkom šumskom području-sistem mera podrške i model organizovanja [Small and medium enterprises in Timok forest area - system of support measures and model of organization]. Beograd: Univerzitet Beogradu-Šumarski fakultet.

[23] Schwienbacher, A. (2007). A theoretical analysis of optimal financing strategies for different types of capital-constrained entrepreneurs. Journal of Business Venturing 22(6), 753-781. doi:10.1016/j.jbusvent.2006.07.003

[24] St-Jean, E., LeBel, L., \& Audet, J. (2010). Entrepreneurial orientation in the forestry industry: a population ecology perspective. Journal of Small Business and Enterprise Development 17(2), 204-217. doi:10.1108/14626001011041210

[25] Swoboda, B., \& Olejnik, E. (2013). A taxonomy of small- and medium-sized international family firms. Journal of International Entrepreneurship 11(2), 130-157. doi:10.1007/s10843-012-0101-x 
[26] Uddin, M.S., Mukul, S.A., Khan, M.A.S.A., Alamgir, M., Harun, Md.Y., \& Ala, M.S. (2008). Small-scale Agar (Aquilaria agallocha Roxb.) Based Cottage Enterprises in Maulvibazar District of Bangladesh: Production, Marketing and Potential Contribution to Rural Development. Small-scale Forestry 7(2), 139-149. doi:10.1007/s11842-008-9046-2

[27] USAID (2008). Herbs, mushrooms and forest fruit (medicinal and aromatic plants): Value chain assessment. Belgrade: USAID Agribusiness Project.

[28] Westhead, P., Ucbasaran, D., Wright, M., \& Binks, M. (2005). Novice, Serial and Portfolio Entrepreneur Behaviour and Contributions. Small Business Economics 25(2), 109-132. doi:10.1007/s11187-003-6461-9

Receieved: June 2014. Accepted: September 2014.

\section{$1 / 1 / 1 / 1 / 1 / 1 / 1 / 1 / 1 / 1 / 1 / 1 / 1 / 1 / 1 /$ abouthe eathor}

\section{Dragan Nonić \\ University of Belgrade, Faculty of Forestry, Serbia dragan.nonic@sfb.bg.ac.rs}

Dr. Dragan Nonić is associated professor at the Faculty of Forestry, University of Belgrade and Head of Forestry Economics and Organisation. He teaches the followng courses: organisation and management in forestry and nature protection,

entrepreneurship and SMEs in forestry, and governance in forestry and nature protection at both BSc, MSc and PhD levels. As the author or co-author, he has published a textbook, several monographs and around 200 papers in national and international scientific journals. He has been coordinator of "Tempus", DAAD and European Forest Institute projects, and collaborates as an expert in FAO, World Bank and regional projects. He was a visiting researcher at Albert Ludwigs Universität Freiburg, ETH - Zürich and BOKU - Wien, and a visiting professor at the University in Sarajevo and the University of Banja Luka. Dr. Dragan Nonić is Alexander von Humboldt and DAAD Foundation's Alumni.

\section{Jelena Nedeljković \\ University of Belgrade, Faculty of Forestry, Serbia jelena.nedeljkovic@sfb.bg.ac.rs}

Jelena Nedeljković, graduate engineer, is research assistant at the Faculty of Forestry, University of Belgrade. Her fields of research interest are: organisation and management in forestry, entrepreneurship and SMEs in forestry and governance in nature protection. She has been a co-author of around 30 scientific papers and several national and international monographs, and also participated in international research projects. She was granted European Forest Institute (EFI) scholarships for PhD students and was a visiting researcher at EFI Mediterranean Regional Office - Barcelona and BOKU - Wien.

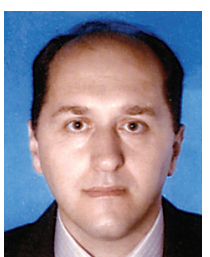

Nenad Ranković University of Belgrade, Faculty of Forestry, Serbia nenad.rankovic@sfb.bg.ac.rs

Dr. Nenad Ranković is full professor at the Faculty of Forestry, University of Belgrade, where he teaches courses in forest economics, forest policy, and trade and marketing of forest products at BSc, MSc and PhD levels. He has published, as author and co-author, 3 books, 4 monographs and more than 140 papers in national and international scientific journals. As coordinator or participant, he has been involved in several

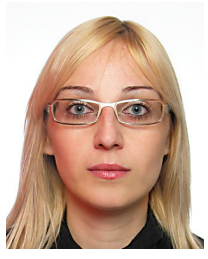
research projects. 